F. Reprod. Fert. (1968) 17, 263-273

\title{
IN VITRO SYNTHESIS OF ANDROGENS BY TESTICULAR TISSUE OF RAT DEFICIENT IN ESSENTIAL FATTY ACIDS
}

\author{
B. AHLUWALIA, S. SHIMA AND G. PINCUS \\ The Worcester Foundation for Experimental Biology, \\ Shrewesbury, Massachusetts, U.S.A.
}

(Received 30th October 1967, accepted 22nd March 1968)

\begin{abstract}
Summary. Slices of testes from normal rats and rats fed diets deficient in essential fatty acids (EFA) were incubated with $\left[1-{ }^{14} \mathrm{C}\right]$ acetate, $\left[7 \alpha-{ }^{3} \mathrm{H}\right]$ cholesterol and $\left[4-{ }^{14} \mathrm{C}\right]$ progesterone as substrates. Incorporation of activity in testosterone and androstenedione was measured.

With $\left[1-{ }^{14} \mathrm{C}\right]$ acetate and $\left[7 \alpha-{ }^{3} \mathrm{H}\right]$ cholesterol as substrates there was an approximate doubling in the yield of testosterone and androstenedione in the testes of EFA-deficient rats, but with $\left[4-{ }^{14} \mathrm{C}\right]$ progesterone as substrate the differences between groups were not marked. It is postulated that increased biosynthesis of androgens (from acetate and cholesterol substrates) in EFA-deficient animals is perhaps due to structural changes in the mitochondrial wall causing increased permeability of the substrate to the mitochondrial enzymes. No change in the yield of androgens with $\left[4-{ }^{14} \mathrm{C}\right]$ progesterone as precursor is perhaps due to non-involvement of mitochondria for synthesis of progesterone $\rightarrow$ androgens in the rat testis.
\end{abstract}

\section{INTRODUGTION}

Essential fatty acid (EFA) deficiency has been known to result in reproductive failures in both male and female rats (Burr \& Burr, 1929, 1930). In females, delayed implantation, prolonged gestation, foetal maceration and resorption were observed (Evans, Lepkovsky \& Murphy, 1934a, b). In males, impaired sexual drive and sterility were striking (Evans, Lepkovsky \& Murphy, 1934c). Histological examination of the testes of EFA-deficient animals indicated tubular degeneration and spermatogenic arrest, the spermatogenesis having failed to go beyond the secondary spermatocyte stage (Alfin-Slater \& Bernick, 1958; Panos \& Finerty, 1954); these changes in the testes were reversed following gonadotrophin therapy (Panos, Klein \& Finerty, 1959). Microscopic changes in the cellular morphology of the hypophysis similar to those observed in the hypogonadism suggest that testicular androgens were not secreted (Panos \& Finerty, 1954; Panos et al., 1959). Similar data describing the changes in the pituitary morphology, testicular morphology and impaired sex drive are reported in the EFA-deficient rabbits (Ahluwalia, Pincus \& Holman, 1967). 
However, histochemical studies in the rat (unpublished) and in the rabbit (Ahluwalia $e t$ al., 1967) indicated the presence of enzymes ( $\Delta^{5}-3 \beta$-hydroxysteroid dehydrogenase, glucose-6-phosphate dehydrogenase) involved in steroid biosynthesis. These studies, therefore, appear to suggest that gonads are capable of secreting androgens; whether these are in sufficient quantities is not known. Because of the histochemical evidence of the presence of enzyme necessary for testicular androgen production, it seemed pertinent to investigate whether androgen production was decreased or whether the target organs were incapable of responding to the circulating androgens (Southren, Ross, Sharma, Gordon, Weingold \& Dorfman, 1965; French, Van Wyk, Baggett, Easterling, Talbert, Johnston, Forchielli \& Dey, 1966; Wilkins, 1957). In this report androgen production in the testes of EFA-deficient rats was investigated using various exogenous radio-active precursors.

\section{MATERIAL AND METHODS}

Thirty-one weanling, male Sprague-Dawley rats were fed a semi-synthetic, fat-deficient diet for periods of up to 100 days. The percentage composition of the experimental diet was as follows: fat-free casein 18.0 ; sucrose 70.0 ; cellulose 4.0 , and wesson salt 4.0 ; in addition, the feed mixture contained (mg per $\mathrm{kg}$ ) vitamin A, $5 \cdot 0(20,000$ units $/ \mathrm{g})$; calciferol, $0 \cdot 1 ; \alpha$-tocopherol, $10 \cdot 0 ;$ ascorbic acid, 500; calcium pantothenate, $70 \cdot 0$; inositol, $1 \cdot 32$; 2-methyl-1,4-napthoquinone, $5 \cdot 0$; niacin, $50 ; p$-aminobenzoic acid, 500 ; pyridoxine hydrochloride, 30.0 ; riboflavin, 30.0 ; thiamine hydrochloric acid, 73.0 ; choline, 13.2 ; folic acid, 11.0; biotin, 9.5; and vitamin $B_{12}, 2 \cdot 0$. An equal number of animals was used as a control and fed a commercial diet (Purina Laboratory Chow). The animals were fed and watered freely. All animals were kept on their diet for a minimum of 70 days; at the end of this period, four animals chosen randomly from each group were killed; the testes were excised and stored in $20 \mathrm{ml}$ of physiological normal saline at $-20^{\circ} \mathrm{C}$ until the time of analysis.

\section{Lipid extraction and gas-liquid chromatography $(G L C)$}

The tissues were thawed, homogenized (Omni mixer, Servall), and the lipids extracted with 20 vol. of chloroform-methanol $(2: 1 \mathrm{v} / \mathrm{v})$ according to the procedure described by Folch, Lees \& Sloane Stanley (1957). An aliquot of lipids was transesterified with $5 \% \mathrm{HCl}$-methanol and the methyl esters were analysed by GLC. A Gas Chromatograph (Research Specialty) with a hydrogen flame detector was used. Throughout the experiment a U-shaped glass column $6 \mathrm{ft} \times \frac{1}{4}$ in. was packed with $20 \%$ ethylene glycol succinate with $2 \%$ phosphoric acid on Gas-Chrom P, 80 to 100 mesh. Helium was used as carrier gas at a flow rate of 80 to $90 \mathrm{ml} / \mathrm{min}$. Column temperature was set at 190 to $195^{\circ} \mathrm{C}$. The fatty acid esters were identified by calculated equivalent chain length (Hofstetter, Sen \& Holman, 1965) and by comparison of retention times with authentic standards obtained from the Hormel Institute, Austin, Minnesota. The fatty acid esters were quantitated by triangulation of the area under appropriate curves obtained from GLC charts, and the data are reported as area of total fatty acids. Amounts less than $0.1 \%$ are expressed as trace. 
In vitro incubations

After being fed the fat-free diet for 70 days, the animals were divided into three groups of nine each. One of the following radio-active precursors was used in each incubation: $\left[1-{ }^{14} \mathrm{C}\right]$ acetate sodium salt, specific activity (s.a.) $20 \mathrm{mc} /$ $\mathrm{m}$-mole; $\left[4-{ }^{14} \mathrm{C}\right]$ progesterone, s.a. $56 \cdot 0 \mathrm{mc} / \mathrm{m}$-mole; $\left[7 \alpha-{ }^{3} \mathrm{H}\right]$ cholesterol, s.a. $9 \cdot 8$ $\mathrm{c} / \mathrm{m}$-mole. All radio-active chemicals were obtained from New England Nuclear Corporation. The purity of steroid radiochemicals before use was determined by thin-layer chromatography (TLG) prepared from silica gel $\mathrm{GF}_{254}$, in the solvent systems used for analysis of products. An analysis in each group (nine rats) was accomplished in 10 days time so that the first group was completed within 70 to 80 days, another group between 80 and 90 days, and the last group between 90 and 100 days after being started on the experimental diet.

\section{Incubation conditions}

Three experiments were conducted in each of which eighteen animals were used: nine from the control group and nine from the group which had been maintained on the fatty-acid-deficient diet.

In each experiment, testicular tissue from three rats of each group was incubated with each of the following radio-active precursors: $\left[1-{ }^{14} \mathrm{C}\right]$ sodium acetate $(10 \mu \mathrm{c}),\left[7 \alpha^{3} \mathrm{H}\right]$ cholesterol $(25 \mu \mathrm{c})$ and $\left[4-{ }^{14} \mathrm{C}\right]$ progesterone $(0 \cdot 5 \mu \mathrm{c})$. The animals were killed by cervical dislocation and duplicate samples of $500 \mathrm{mg}$ of tissue were removed from each animal, and transferrred immediately to a petri dish placed on crushed ice. The tissues were minced and distributed into $50-\mathrm{ml}$ Erlenmeyer flasks containing $6.0 \mathrm{ml}$ of sodium bicarbonate buffer at $\mathrm{pH} 7.4$ (Hanks' solution, Difco Laboratories, Detroit, Michigan). Before the addition of buffer and the tissue to the flask, the radio-active substrate was dried under a stream of nitrogen; and approximately five drops of propylene glycol were added to the flasks containing $\left[4-{ }^{14} \mathrm{C}\right]$ progesterone and $\left[7 \alpha-{ }^{3} \mathrm{H}\right]$ cholesterol precursors: the $\left[1-{ }^{14} \mathrm{C}\right]$ acetate precursor was used without solvent. The incubations were carried out in a Dubnoff metabolic incubator at $37^{\circ} \mathrm{C}$ for $3 \mathrm{hr}$ in an atmosphere of $95.0 \% \mathrm{O}_{2}$ and $5.0 \% \mathrm{CO}_{2}$. At the end of incubation $10 \mathrm{ml}$ of ethyl acetate were added to each flask to stop all enzymic reactions.

\section{Extraction}

At the conclusion of incubation, $50 \mu \mathrm{g}$ each of carrier testosterone and androstenedione were added to each flask. Also added were trace amounts $\left(15,000\right.$ counts $/ \mathrm{min}$ ) of $\left[1,2,{ }^{3} \mathrm{H}_{2}\right]$ testosterone (s.a. $46.5 \mathrm{c} / \mathrm{m}$-mole) and $[1,2-$ $\left.{ }^{3} \mathrm{H}_{2}\right]$ androstenedione (s.a. $10 \cdot 0 \mathrm{c} / \mathrm{m}$-mole) to flasks with! $\left[1{ }^{14} \mathrm{C}\right]$ acetate and $\left[4-{ }^{14} \mathrm{C}\right]$ progesterone precursor, and to flasks with $\left[7 \alpha^{3} \mathrm{H}\right]$ cholesterol as precursor; trace amounts of $\left[4-{ }^{14} \mathrm{C}\right]$ testosterone (s.a. $3 \cdot 7 \mathrm{mc} / \mathrm{m}-\mathrm{mole}$ ) and $\left[4-{ }^{14} \mathrm{C}\right]-$ androstenedione (s.a. $45.2 \mathrm{mc} / \mathrm{m}$-mole) were added to calculate the recovery. The contents of the flask were homogenized and extracted repeatedly with $5 \times 10 \mathrm{ml}$ of ethyl acetate. The combined extracts were evaporated to dryness under reduced pressure and the residue dissolved in $30 \mathrm{ml}$ of light petroleum (b.p. $45^{\circ} \mathrm{C}$ ). The latter was extracted four times with $10 \mathrm{ml}$ of $70 \%$ aqueous methanol. The pooled $70 \%$ aqueous methanol phases were evaporated to an aqueous 
residue which was then extracted five times with $10 \mathrm{ml}$ of dichloromethane (Zander, 1962). The pooled dichloromethane extract was evaporated to a small volume and then chromatographed on TLC in a solvent system of diethyl ether and ethyl acetate $(2: 5 \mathrm{v} / \mathrm{v})$ (Zander, Forbes, Von Münstermann \& Neher, 1958). In this system testosterone and 17-hydroxyprogesterone had the same mobility. The latter were clearly separated from androstenedione.

In order to isolate testosterone from $17 \alpha$-hydroxyprogesterone, the area containing these compounds was eluted and acetylated for $24 \mathrm{hr}$ at room temperature (Hall, Sozer \& Eik-Nes, 1964). The acetylated compound was dried and extracted repeatedly with $2 \mathrm{ml}$ of $50 \%$ dichloromethane and with methanol four times; the extract was reduced to a small volume and rechromatographed on TLC in the solvent system containing benzene and dichloromethane $(3: 2 \mathrm{v} / \mathrm{v})$ (Hall, 1963). The area corresponding to testosterone acetate was determined by reference to a standard run in parallel and was eluted with $50 \%$ dichloromethane and methanol. An aliquot of eluates was used to measure the radio-activity by liquid scintillation spectrometry (Hall \& Eik-Nes, 1962). The solution used for counting contained $5 \mathrm{~g}$ PPO (2,5-diphenyloxazole) and $0.1 \mathrm{~g}$ POPOP (1,4-bis-2-(5-phenyloxazolyl)-benzene)/1 of toluene. Recovery of testosterone and androstenedione by this method was 65 to $75 \%$. The counting efficiency disintegrations $/ \mathrm{min}$ for ${ }^{14} \mathrm{C}$ and ${ }^{3} \mathrm{H}$ were $62.5 \%$ and $32.3 \%$ respectively.

\section{Histological studies}

Pituitary glands from six rats selected randomly (two from each group of those used in in vitro incubation studies) were removed, cleaned and immediately fixed in chrome alum fixative (Elftman, 1957) for $24 \mathrm{hr}$ for routine tissue sectioning. The sections $(6 \mu)$ were stained by Loxol-fast-blue-periodic-acidSchiff-haematoxylin staining technique (McManus \& Mowry, 1965).

\section{RESULTS}

At the end of 60 days of the dietary regimen, the animals on EFA-deficient diets showed typical deficiency symptoms, e.g. scaly tail, necrosis in the hind legs and loss of hair in the back. These symptoms grew more severe with prolonged feeding of the diets. These observations are consistent with the wellknown symptoms of EFA deficiency (Holman, 1954). In order to ensure that these animals, in addition to their gross EFA deficiency symptoms, also showed typical biochemical changes in the testicular lipids before incubation studies, the fatty acid composition of testes was analysed (Table 1).

These data show a marked increase in 5,8,11-eicosatrienoic acid $(20: 3 \omega 9)$ and a decrease in the linoleic acids $(18: 2 \omega 6)$ and their major metabolites

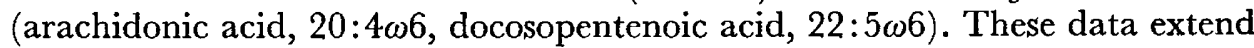
the results of numerous reports in the literature describing the typical lipid changes in the EFA deficiency (Holman, 1960). In EFA-deficient tissue, an accumulation of $20: 3 \omega 9$ fatty acids and decrease of linoleic acid (18:2 $\omega 6)$ and its metabolites have been shown to be the major biochemical changes (Fulco \& Mead, 1959). In Table 2, data on body weights, weights of testes and 


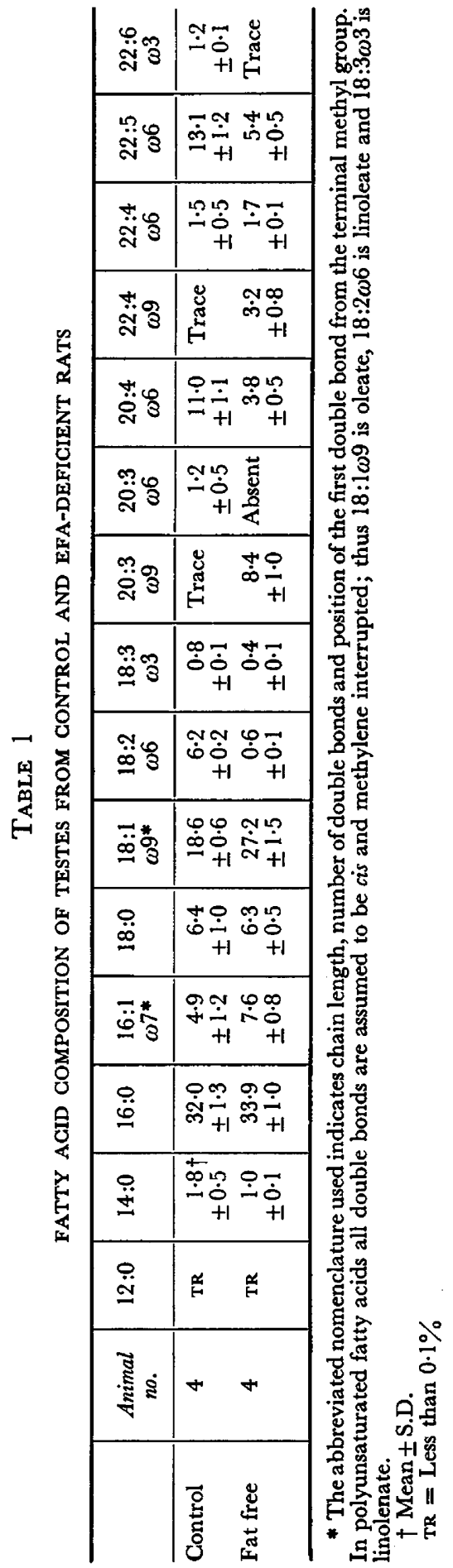


male accessory glands are presented. There is a significant reduction $(P<0.01)$ in the weight of male accessory glands in the deficient animal. The differences in the testes weights and body weights were not significant.

TABLE 2

BODY WEIGHTS AND WEIGHTS OF TESTES AND MAIE AGCESSORY GLANDS IN THE CONTROL AND EFA-DEFIGIENT ANIMALS

\begin{tabular}{l|c|c|c|c|c|c}
\hline \multicolumn{1}{c|}{ Group } & $\begin{array}{c}\text { No. of } \\
\text { animals }\end{array}$ & Age (days) & Body $(\mathrm{g})$ & Testes $(\mathrm{g})$ & $\begin{array}{c}\text { Seminal } \\
\text { vesicles }(\mathrm{mg})\end{array}$ & $\begin{array}{c}\text { Ventral } \\
\text { prostate }(\mathrm{mg})\end{array}$ \\
\hline $\begin{array}{l}\text { Control } \\
\text { Deficient }\end{array}$ & 12 & 110 to 130 & $291 \pm 24 *$ & $2 \cdot 8 \pm 1 \cdot 0$ & $\begin{array}{l}473 \pm 34 \\
110 \pm 24 \dagger\end{array}$ & $\begin{array}{c}344 \pm 37 \\
197 \pm 14 \dagger\end{array}$ \\
\hline
\end{tabular}

$*$ Mean \pm S.D.

$\dagger P<0.01$ (differences between control and deficient). Others non-significant.

TABLE 3

RADIOCHEMICAL PURITY OF RADIO-ACTIVE TESTOSTERONE ACETATE FROM POOLED SAMPLES IN CONTROL AND DEFICIENT ANIMALS*

\begin{tabular}{c|c|c|c|c|c|c|c}
\hline \multirow{2}{*}{ Cryst. no. } & \multicolumn{8}{|c}{ Group $\dagger$} \\
\cline { 2 - 8 } & 1 & 2 & 3 & 4 & 5 & 6 & 7 \\
\hline 1 & 1113 & 2340 & 1410 & 1880 & 3120 & 4170 & 4110 \\
2 & 1140 & 2190 & 1380 & 1320 & 3840 & 4050 & 5160 \\
3 & 1140 & 2100 & 1440 & 1350 & 3930 & 4110 & 4800 \\
\hline
\end{tabular}

* Specific activity disintegrations/min/mg.

$\uparrow$ Groups 1 to 7 were selected randomly (from either control or deficient) from groups listed in Table 5.

TABLE 4

RADIOCHEMICAL PURITY OF RADIOACTIVE ANDROSTENEDIONE FROM POOLED SAMPLES IN CONTROL AND DEFIGIENT ANIMALS*

\begin{tabular}{c|r|r|r}
\hline \multirow{2}{*}{ Cryst. no. } & \multicolumn{3}{|c}{ Group $\dagger$} \\
\cline { 2 - 4 } & 1 & \multicolumn{1}{|c}{2} & 3 \\
\hline 1 & 1458 & 1104 & 3690 \\
2 & 1290 & 801 & 2864 \\
3 & 1260 & 837 & 2850 \\
\hline
\end{tabular}

* Specific activity disintegrations/min/mg.

$\uparrow$ The groups 1 to 3 (from either control or deficient) were chosen randomly from the groups described in Table 5.

Tables 3 and 4 demonstrate the radiochemical purity of testosterone acetate and androstenedione isolated by the method used in this study. The testosterone acetate and androstenedione from the duplicate incubations were pooled and seven of the nine samples for testosterone acetate and three samples of 


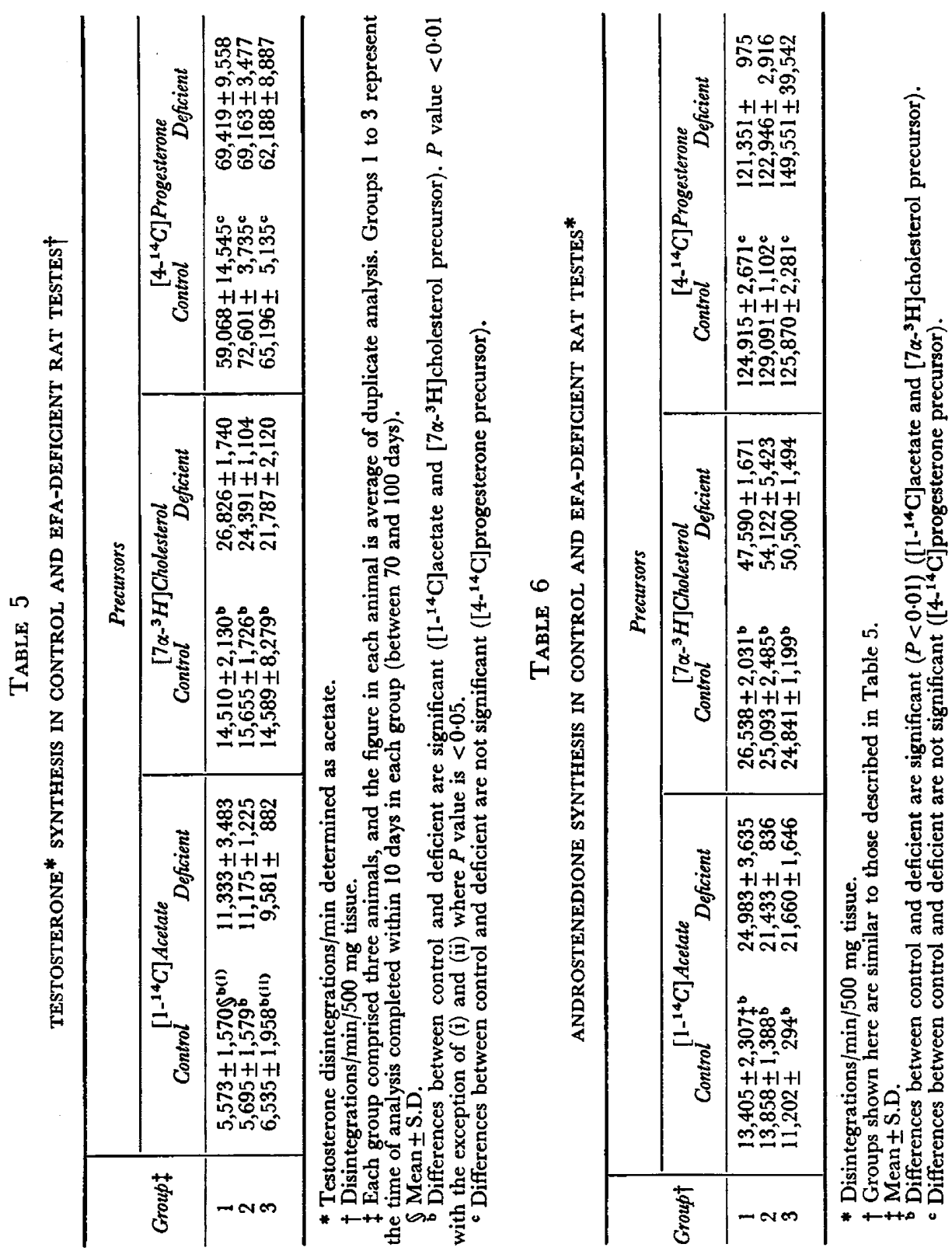


androstenedione were chosen at random and after addition of carrier were recrystallized to constant specific activity from three different solvent systems (Zander et al., 1958). The specific activity upon recrystallization did not change appreciably, thereby demonstrating radiochemical homogeneity of the isolated steroids.

Tables 5 and 6 show the data on testosterone and androstenedione synthesis. There was a significant increase in the yield of testosterone and androstenedione in the deficient tissue when $\left[1-{ }^{14} \mathrm{C}\right]$ acetate and $\left[7 \alpha-{ }^{3} \mathrm{H}\right]$ cholesterol were used as precursors; however, with $\left[4-{ }^{14} \mathrm{C}\right]$ progesterone incubations, the differences were not marked.

The histological examination of the pituitary, stained by Luxol-fast-bluePAS (PI. 1, Figs. A and B), revealed that, in the deficient animal, PAS-positive basophil cells were hypertrophied and the cytoplasm filled with colloid particles. The microscopic appearance of these cells (Signet-ring cells) resembles those described in the spayed animal (Purves \& Griesbach, 1955). Panos et al. (1959) have described similar changes in the pituitary of fat-deficient rats. First appearance of hypertrophied or spaying cells were observed between 70 and 80 days of deficient diet, and thereafter there was a progressive increase in the number of these cells. With the staining technique used in this study, it is not possible to make a positive differentiation between two types of basophils (FSH and LH type).

\section{DISGUSSION}

The data presented here extend the results of several studies in the past describing male infertility in EFA-deficient animals (Panos et al., 1959; Greenberg \& Ershoff, 1951). In the study reported here, there was a significant reduction in the weights of male accessory glands (Table 2) in the deficient animals which suggests insufficiency of androgen secretion; however, our previous histochemical studies in the deficient animal have indicated the presence of enzymes $\left(\Delta^{5}-3 \beta\right.$-hydroxydehydrogenase, glucose-6-phosphatase) involved in steroid biosynthesis in the testes (unpublished observations). The adequacy of testicular androgen biosynthesis was confirmed in the present study (Tables 5 and 6). But the most intriguing result arising from these studies is that there is a significant increase in the yield of testosterone and androstenedione in the deficient testes. The reason for increased yield of androgen in the deficient animal cannot be explained on the basis of this data, but the following explanation has been presented from the results of several studies.

Changes in the composition of the dietary fat influence the composition of subcellular particles (Rahm \& Holman, 1964; Bartley, 1964) and, therefore, may affect the rate of cellular metabolism (Rahm \& Holman, 1964). Other studies have shown that essential fatty acids may satisfy a structural requirement in normal cell membrane (Aaes-Jørgensen, 1961), and they may be essential components in the lipid enzyme complexes of subcellular particles (Klein \& Johnson, 1954). In EFA deficiency, increased metabolic rate (Burr \& Beber, 1937), increased membrane permeability (Hayashida \& Portman, 1963) and increased swelling (Hayashida \& Portman, 1960; Johnson, 1963; 


\section{PLAIE 1}

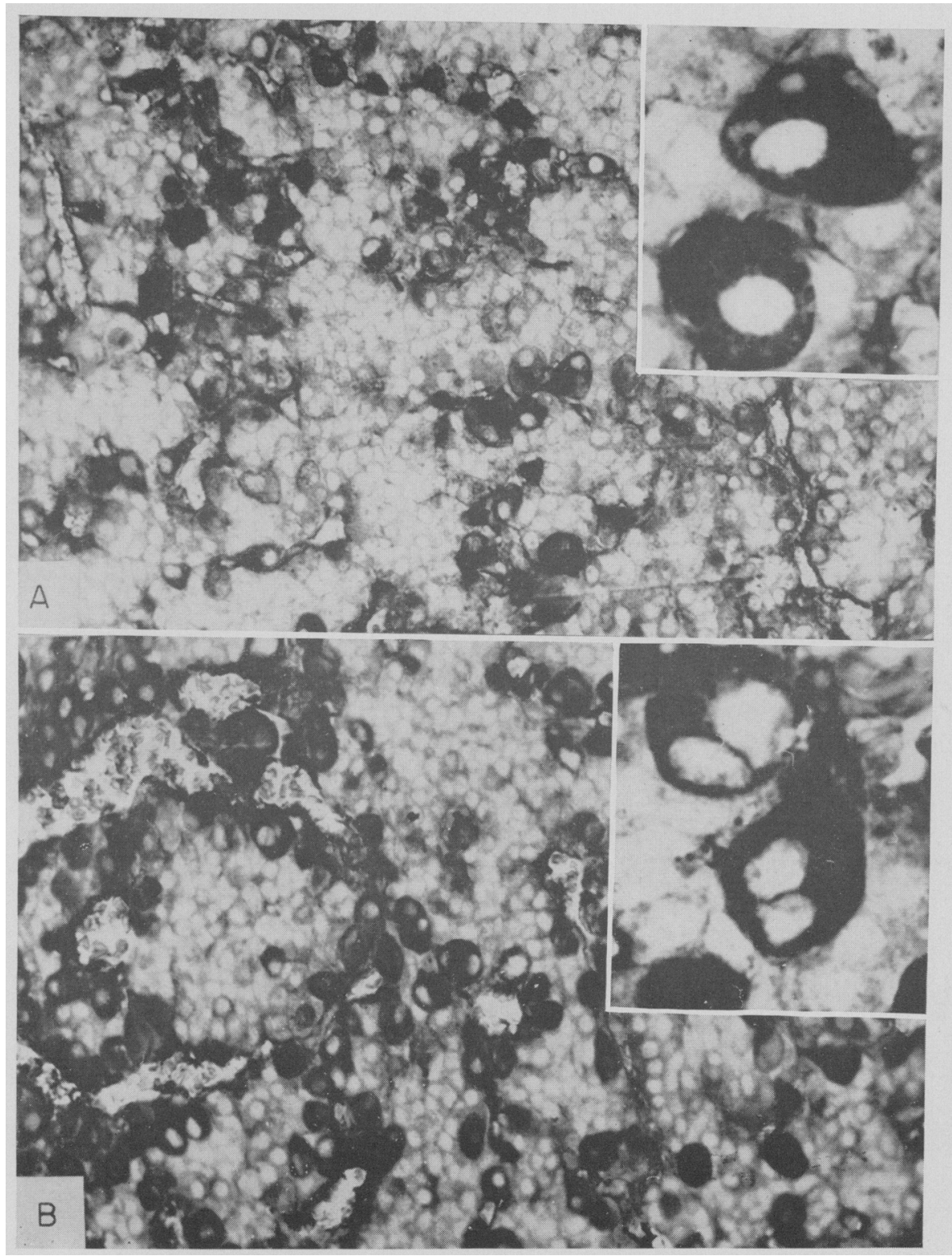

A. Anterior Pituitary) Sex zone of normal rat stained with PAS photographed through a green filter. The normal distribution and granulation of basophils is depicted. $\times 1125$. Inset: High magnification of normal basophils; the clear space corresponds to the nucleus. $\times 3600$.

B. Sex zone of EFA-deficient rat stained with PAS and photographed through a green filter. 'The basophil cells are increased in size and number. $\times 1125$. Inset: Many basophils are transformed into castration cells with a larger colloid vacuole adjacent to the nucleus. $\times 3600$. 
Levin, Johnson \& Albert, 1957), perhaps due to structural changes in the mitochondrial membranes (Stein \& Stein, 1964), have been reported previously. These and other related studies suggest a relationship between the swelling tendency and electron transfer and/or uncoupled oxidative phosphorylation in the mitochondria of EFA-deficient rats. The literature cited above concerns liver mitochondria; however, our current investigation on the swelling studies of mitochondria of EFA-deficient testes revealed similar results (Ahluwalia, Shima \& Pincus, 1968). Further studies on the structural and enzymatic changes in the mitochondria in EFA-deficient animals are under investigation and will be presented elsewhere. In isolated liver mitochondria in vitro studies,

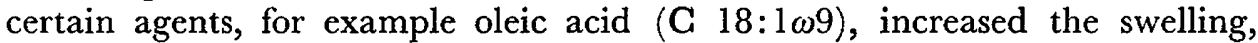
and the degree of swelling is proportional to the concentration of oleates in the medium (Utsumi, Ohara, Yamamoto, Inaba, Urkami \& Yamamoto, 1962). This fatty acid is known to increase significantly in EFA deficiency (Table 1); whether this would also increase mitochondrial swelling in vivo is speculative.

On the basis of this information, therefore, it is possible that an increased yield of androgens from $\left[1-{ }^{14} \mathrm{C}\right]$ acetate and $\left[7 \alpha-{ }^{3} \mathrm{H}\right]$ cholesterol as precursors in in vitro incubations is perhaps due to structural alterations in the mitochondria wall, causing increased permeability of exogenous precursors to the enzymes located on the mitochondria.

When $\left[4-{ }^{14} \mathrm{C}\right]$ progesterone was used as precursor, there was no difference in the yield of testosterone and androstenedione in either group. It is difficult to postulate the reason for these data; however, on the basis of several studies, there is evidence that the steps for conversion of cholesterol $\rightarrow 2 \alpha$-hydroxycholesterol $\rightarrow 20 \alpha, 22$-dihydroxycholesterol $\rightarrow$ pregnenolone take place in the mitochondrial particles in adrenals (Halkerston, Eichhorn \& Hechter, 1961), corpus luteum (Hall \& Koritz, 1964) and testes (Menon, Drosdowsky, Dorfman $\&$ Forchielli, 1965), and the conversion of pregnenolone $\rightarrow$ androgens occurs in the microsomal particles (Samuels, 1960). It would, therefore, appear that since there is no change in amounts of androgen production from $\left[4-{ }^{14} \mathrm{C}\right]$ progesterone in EFA-deficient rat testes, the steps for conversion from pregnenolone to androgens outside the mitochondria remained essentially intact in this deficiency. Meanwhile we do not exclude the possibility that increased pituitary gonadotrophins (LH) in EFA deficiency (Panos, 1963) could also bring about increased biosynthesis of androgens (Major, Armstrong \& Greep, 1967). Hypertrophied basophils (spayed-type cells) as shown in our study (Pl. 1, Figs. A and B) in the deficient animal suggest increased gonadotrophins in the pituitary of deficient animals (Rennels, 1957). Studies are currently planned to determine the LH contents of pituitary and plasma in the deficient animals.

The increased capacity of EFA-deficient testes to synthesize androgens from exogenous precursors seems to contradict the significant decrease in the weights of male accessory glands (Table 2) in the deficient animal. However, an explanation that the sensitivity of targets (male accessory glands) to circulating androgens is decreased in EFA deficiency could be applicable to this discrepancy (unpublished observations). Southren et al. (1965) have postulated that the absence of virilization in the human female due to presence of feminizing 
testes is due to insensitivity of the end organs to normal levels of circulating androgens.

The studies are planned in our laboratory and the data obtained so far confirm some of the postulations offered in the study presented here. Whether a single factor or a combination of various factors results in increased biosynthesis of androgens in EFA deficiency needs to be confirmed.

\section{ACKNOWLEDGMENTS}

This investigation was supported in part by a grant from G. D. Searle and Company. One of the authors (B.A.) is a recipient of National Institutes of Health Special Fellowship 1F3 HD23,963-01.

\section{REFERENCES}

Aaes-Jørgensen, E. (1961) Essential fatty acids. Physiol. Rev. 41, 1.

Ahluwalia, B. S., Pincus, G. \& Holman, R. T. (1967) Essential fatty acid deficiency and its effects upon reproductive organs of male rabbits. $\mathcal{F}$. Nutr. 92, 205.

Ahluwalia, B., Shima, S. \& Pincus, G. (1968) In vitro and in vivo biosynthesis of androgens in the testes of essential fatty acid deficient rat. Fedn Proc. Fedn Am. Socs exp. Biol. $27,2$.

Alfin-Slater, R. B. \& Bernick, S. (1958) Changes in tissue lipids and tissue histology resulting from essential fatty acid deficiency in rats. Am. $\mathscr{\mathcal { F }}$. clin. Nutr. 6, 613.

Bartezy, W. (1964) In: Metabolism and significance of lipids, p. 369. Eds. D. N. Rhodes and R. M. C. Dawson. Wiley, London.

Burr, G. O. \& Beber, A. J. (1937) Metabolism studies with rats suffering from fat deficiency. F. Nutr. 14, 553.

BURR, G. O. \& Burr, M. M. (1929) A new deficiency disease produced by the rigid exclusion of fat from the diet. F. biol. Chem. 82, 345.

BURR, G. O. \& BURR, M. M. (1930) On the nature and rôle of the fatty acids essential in nutrition. 7. biol. Chem. 86, 587.

Elfrman, H. (1957) A chrome-alum fixative for the pituitary. Stain Technol. 32, 25.

Evans, H. M., Lepkovsky, S. \& Murphy, E. A. (1934a) Vital need of the body for certain unsaturated fatty acids. IV. Reproduction and lactation upon fat-free diets. 7. biol. Chem. 106, 431.

Evans, H. M., Lepkovsky, S. \& MURPhy, E. A. (1934b) Vital need of the body for certain unsaturated fatty acids. V. Reproduction and lactation upon diets containing saturated fatty acids as their sole source of energy. F. biol. Chem. 106, 441.

Evans, H. M., Lepkovsky, S. \& MURPhy, E. A. (1934c) Vital need of the body for certain unsaturated fatty acids. VI. Male sterility on fat-free diets. F. biol. Chem. 106, 445.

Folch, J., Lees, M. \& Sloanz-Stanley, G. H. (1957) A simple method for the isolation and purification of total lipids from animal tissues. 7. biol. Chem. 226, 497.

French, F. S., Van Wyk, J. J., Baggett, B., Easterling, W. E., Talbert, L. M., Johnston, F. R., Forchielis, E. \& DeY, A. C. (1966) Further evidence of a target organ defect in the syndrome of testicular feminization. F. clin. Endocr. Metab. 26, 493.

Fulco, A. J. \& MEAD, J. F. (1959) Metabolism of essential fatty acids. VIII. Origin of 5,8,11-eicosatrienoic acid in the fat-deficient rat. 7. biol. Chem. 234, 1411.

Greenberg, S. M. \& Ershopr, B. H. (1951) Effects of chorionic gonadotropin on the sex organs of male rats deficient in essential fatty acids. Proc. Soc. exp. Biol. Med. 78, 552.

Halkerston, I. D. K., EichhorN, J. \& Hechter, O. (1961) A requirement for reduced triphosphopyridine nucleotide for cholesterol side-chain cleavage by mitochondrial fractions of bovine adrenal cortex. J. biol. Chem. 236, 374.

HALl, P. F. (1963) The effect of interstitial-cell-stimulating hormone on the biosynthesis of testicular

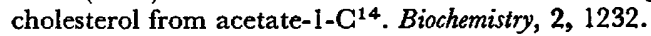

HALl, P. F. \& EIK-NES, K. B. (1962) The action of gonadotropic hormones upon rabbit testis in vitro. Biochim. biophys. Acta, 63, 411 .

Hall, P. F. \& Koritz, S. B. (1964) The conversion of cholesterol and 20a-hydroxycholesterol to steroids by acetone powder of particles from bovine corpus luteum. Biochemistry, 3, 129.

Hall, P. F., Sozer, C. G. \& EIK-Nes, K. B. (1964) Formation of dehydroepiandrosterone during in vivo and in vitro biosynthesis of testosterone by testicular tissue. Endocrinology, 74, 35. 
Hayashida, T. \& Portman, O. W. (1960) Swelling of liver mitochondria from rats fed diets deficient in essential fatty acids. Proc. Soc. exp. Biol. Med. 103, 656.

Hayashida, T. \& Portman, O. W. (1963) Changes in succinic dehydrogenase activity and fatty acid composition of rat liver mitochondria in essential fatty acid deficiency. F. Nutr. 81, 103.

HofstetTeR, H. H., Sen, N. \& Holman, R. T. (1965) Characterization of unsaturated fatty acids by gas-liquid chromatography. 7. Am. Oil Chem. Soc. 42, 537.

Holman, R. T. (1954) Essential fatty acids. In: The Vitamins, Vol. 2, p. 267. Eds. W. H. Sebrell, Jr. and R. S. Harris. Academic Press, New York.

Holman, R. T. (1960) The ratio of trienoic: tetraenoic acids in tissue lipids as a measure of essential fatty acid requirement. $\mathcal{7}$. Nutr. 70, 405.

Johnson, R. M. (1963) Swelling studies on liver mitochondria from essential fatty acid deficient rats. Expl Cell Res. 32, 118.

KLEIN, P. D. \& Johnson, R. M. (1954) Phosphorus metabolism in unsaturated fatty acid-deficient rats. F. biol. Chem. $211,103$.

Levin, E., Johnson, R. M. \& Albert, S. (1957) Mitochondrial changes associated with essential fatty acid deficiency in rats. F. biol. Chem. 228, 15.

Major, P. W., Armstrong, D. T. \& Greep, R. O. (1967) Effects of luteinizing hormone in vivo and in vitro on cholesterol conversion to progestins in rat corpus luteum tissue. Endocrinology, 81, 19.

MaManus, J. F. A. \& Mowry, R. W. (1965) Staining methods, 3rd edn, p. 331. Harper \& Row, New York.

Menon, K. M. J., Drosdowsky, M., Dorfman, R. I. \& Forchielli, E. (1965) Side-chain cleavage of cholesterol-26- $\mathrm{C}^{14}$ and $20 \alpha$-hydroxycholesterol-22- $\mathrm{C}^{14}$ by rat testis mitochondrial preparations and the effects of gonadotrophin administration and hypophysectomy. Steroids, Suppl. 1, 95.

Panos, T. C. (1963) Effects of fat deficiency on the endocrine system in rats. F. Pediat. 63, 1167.

Panos, T. C. \& Finerty, J. C. (1954) Effects of a fat free diet on growing male rats with special reference to the endocrine system. $\mathcal{F}$. Nutr. 54, 315.

Panos, T. G., Klein, G. F. \& Finerty, J. C. (1959) Effects of fat deficiency on pituitary gonadrelationships. F. Nutr. 68, 509.

Purves, H. D. \& Griesbach, E. W. (1955) Changes in the gonadotrophins of the rat pituitary after gonadectomy. Endocrinology, 56, 374.

Rahm, J. J. \& Holman, R. T. (1964) The relationship of single dietary polyunsaturated fatty acid to fatty acid composition of lipids from subcellular particles of liver. F. Lipid Res. 5, 169.

Rennels, E. G. (1957) Two functional types of gonadotrophic cells in the rat hypophysis. Z Z Zellforsch. mikrosk. Anat. 45, 464.

Samuels, L. 'T. (1960) Metabolism of steroid hormones. In: Metabolic Pathways, Vol. I, p. 431. Ed. D. M. Greenberg. Academic Press, London.

Southren, A. L., Ross, H., Sharma, D. C., Gordon, G., Weingold, A. B. \& Dorfman, R. I. (1965) Plasma concentration and biosynthesis of testosterone in the syndrome of feminizing testes. 3. clin. Endocr. Metab. 25, 518.

Stein, O. \& STEIN, Y. (1964) Metabolism in vitro of palmitic and linoleic acid in the heart and diaphragm of essential fatty acid-deficient rats. Biochim. biophys. Acta, 84, 621.

Utsumi, K., Ohara, S., Yamamoto, G., Inaba, K., Urakami, H. \& Yamamoto, M. (1962) Mitochondrial swelling and uncoupling activity of long chain fatty acids. Acta med. Okayama, 16, 317.

WILKIns, L. (1957) The diagnosis and treatment of endocrine disorders in childhood and adolescence, p. 276. Charles C. Thomas, Springfield.

Zander, J. (1962) Progesterone. In: Methods in Hormone Research, Vol. I, p. 91. Ed. R. I. Dorfman. Academic Press, London.

Zander, J., Forbes, T. R., Von Münstermann, A. M. \& Neher, R. (1958) $\Delta^{4}$-3-Ketopregnene-20 $\alpha$-ol and $\Delta^{4}$-3-ketopregnene-20 $\beta$-ol, two naturally occurring metabolites of progesterone. Isolation, identification, biologic activity and concentration in human tissues. J. clin. Endocr. Metab. 18, 337. 